\title{
A Memorial Paper on Professor Takatsuki, Who Devoted Himself to the Case Report
}

\author{
Toshio Hattori
}

Citation: Hattori, T. A Memorial Paper on Professor Takatsuki, Who Devoted Himself to the Case Report. Reports 2021, 4, 37. https://doi.org/ $10.3390 /$ reports4040037

Received: 25 September 2021 Accepted: 13 October 2021 Published: 15 October 2021

Publisher's Note: MDPI stays neutral with regard to jurisdictional claims in published maps and institutional affiliations.
Research Institute of Health and Welfare, Kibi International University, Takahashi 716-8508, Japan; hattorit@kiui.ac.jp

This is a memorial paper for Prof. Takatsuki, who discovered three distinct clinical diseases. Heavy chain disease was reported in 1964, and polyneuropathy, organomegaly, endocrinopathy, monoclonal gammopathy, and skin changes (POEMS) were reported in 1992. He also reported adult T cell leukemia in 1976. His important discoveries were based on keen clinical observations and the analysis of clinical materials. The discovery of adult T cell leukemia (ATL) and the independent isolation of human T cell leukemia virus type 1 (HTLV-1) has established a direct causal relationship between ATL and HITV-1. The studies on host-pathogen relationships in ATL led to the expansion of the research in emerging and disaster-related infectious diseases

Prof. Kiyoshi Takatsuki passed away on 23 May 2021, at 90 years of age in Kyoto. He graduated from Kyoto University in 1954. He worked as a physician and demonstrated excellent talent for medical observations of the patients. He worked on diseases associated with plasma cell dyscrasia and worked at Columbia University with Professor E.F. Osserman. They found four cases: (1) proliferation of the cells of the plasmacytic and reticulum cell series, associated with the clinical pattern of a malignant lymphoma; (2) excessive production of polypeptides which are related to the $\mathrm{H}$ (heavy) polypeptide chains of the 7S gamma 2 globulins (designated $H_{\gamma 2}$-chains); and (3) a decrease in the synthesis of normal gamma globulins. These diseases were named as heavy chain diseases as a distinct clinical entity $[1,2]$.

After returning to Japan as a lecturer at Kyoto University, he found a case of POEMS (polyneuropathy, organomegaly, endocrinopathy, monoclonal gammopathy and skin changes) syndrome associated with focal spinal amyloidosis [3] he also summarized 109 cases of POEMS in Japan and reported that this syndrome shows (1) polyneuropathy with increased protein levels in the cerebrospinal fluid and sometimes papilledema; (2) endocrinological symptoms, including skin pigmentation, sclerosis, hypertrichosis, gynecomastia, impotence, amenorrhea, decreased glucose tolerance, edema, pleural effusion and ascites; (3) hepatomegaly, splenomegaly and lymphadenopathy; (4) polycythemia, leukocytosis and thrombocytosis; (5) osteosclerotic changes; and (6) plasma cell dyscrasia [4].

In 1976, he reported that adult T cell leukemia (ATL) shares some features with Sezary syndrome but is distinct. The disease is characterized by (1) adult onset; (2) ATL cells showing characteristic morphologic features, especially deep indented nuclei (Figure 1); (3) frequent associations of skin involvement (Figure 2), lymphadenopathy and hepatosplenomegaly; (4) a high leukemic cell count in the peripheral blood without anemia and with only modest involvement of the bone marrow; (5) hypercalcemia; and (6) a geographic clustering of cases. The most striking feature of ATL, and the original basis of its proposal as a distinct clinical entity, was the clustering of birthplaces of patients in the southwestern part of Japan [5]. 


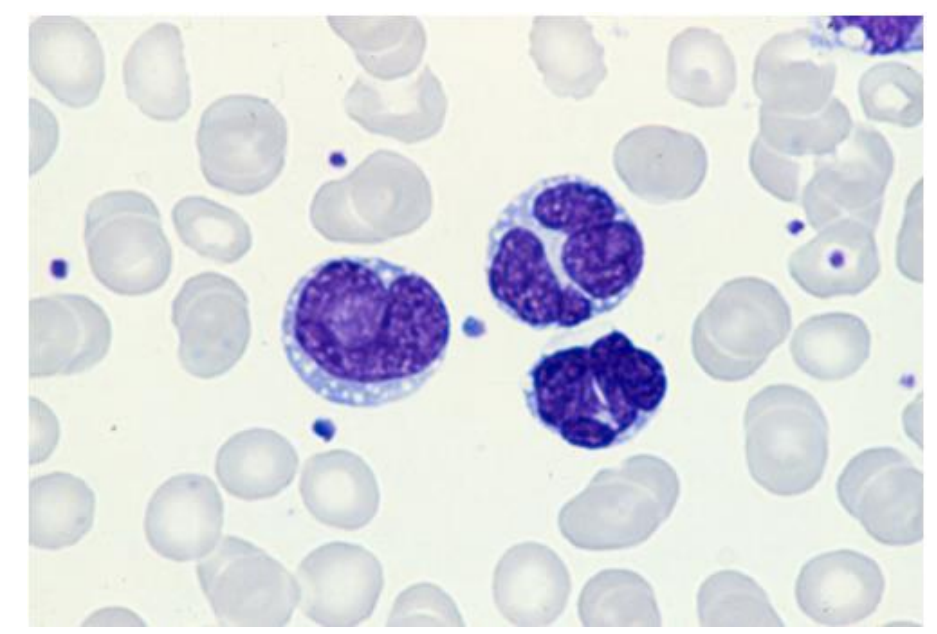

Figure 1. May-Giemsa staining of ATL cells $(\times 400)$. ATL cells with a kidney shape (left), lobulated (center) nuclei and a normal polymorphonucerar cell (lower right).

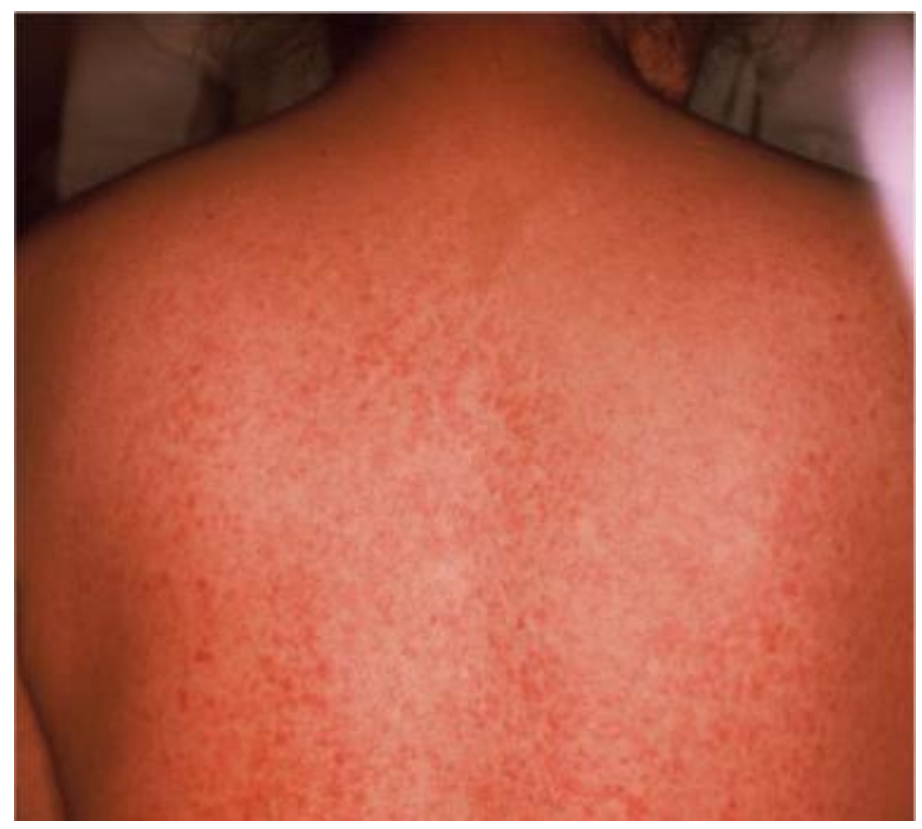

Figure 2. Papular rash in a patient with acute ATL. Various skin lesions including tumors are observed in ATL patients.

In 1980, the isolation of human T-cell leukemia virus type I (HTLV-1) from a patient with cutaneous lymphoma (mycosis fungoides) [6] was reported by Dr. Gallo's group at the National Cancer Institute in the United States. They later noticed the clinical similarities of mycosis fungoides and ATL and subsequently showed that anti-HTLV-1 antibody is prevalent in patients with ATL [7]. The successive collaboration revealed that southwestern Japan was the most endemic area in the world and HTLV-1 was recognized as the first human retrovirus that causes cancer [8,9]. The finding facilitates the discovery of acquired immune deficiency syndrome and human immunodeficiency virus type 1 [10]. These diseases have become a research model of pathogens and their host response to them, and the stimulated research has spread to the study of various infectious diseases. For example, the discovery of osetopontin as a prognostic factor in ATL [11] led to the study of osteopontin in tropical and disaster-related infectious diseases, such as dengue virus infection $[12,13]$. 
Prof. Takatsuki said that he was interested in ATL patients because their face had the characteristics of people of southern descent rather than those of western Japan.

Having been involved in the discovery of three diseases, I have to admit that he had a special power of observation. Of course, the case report was the beginning of these discoveries as written in the editorial of this journal [14]. However, it is not possible to establish a new disease solely by clinical observation. He clarified how to detect heavy chain diseases using papain-digested products [1]. Raising anti-T cell antibodies also helped to establish ATL [15].

He also extended clinical studies which have opened up new research areas. The characterization of ATL cells as CD4+ and CD25+ with suppressive activity contributed to the discovery of regulatory T cells [16]. The findings of the synthesis of chemokines by ATL cells also led to the development of anti-chemokine receptor therapy against ATL [17].

He was awarded the Hammer prize in 1985 and selected as a person of merit of culture in Japan in 1995. The Hammer prize was given to Drs. Gallo, Profs. Takatsuki, Hinuma and Miyoshi. Prof. Hinuma contributed to the detection of antibodies in serum of ATL patients against ATL-derived cell line, MT-1, which was established by Prof. Miyoshi $[18,19]$. The independent work of these scientists and subsequent collaboration established a direct causal relationship between ATL and HTLV-1. This breakthrough was made possible because ATL was clinically established by Prof. Takatsuki (Figure 3).

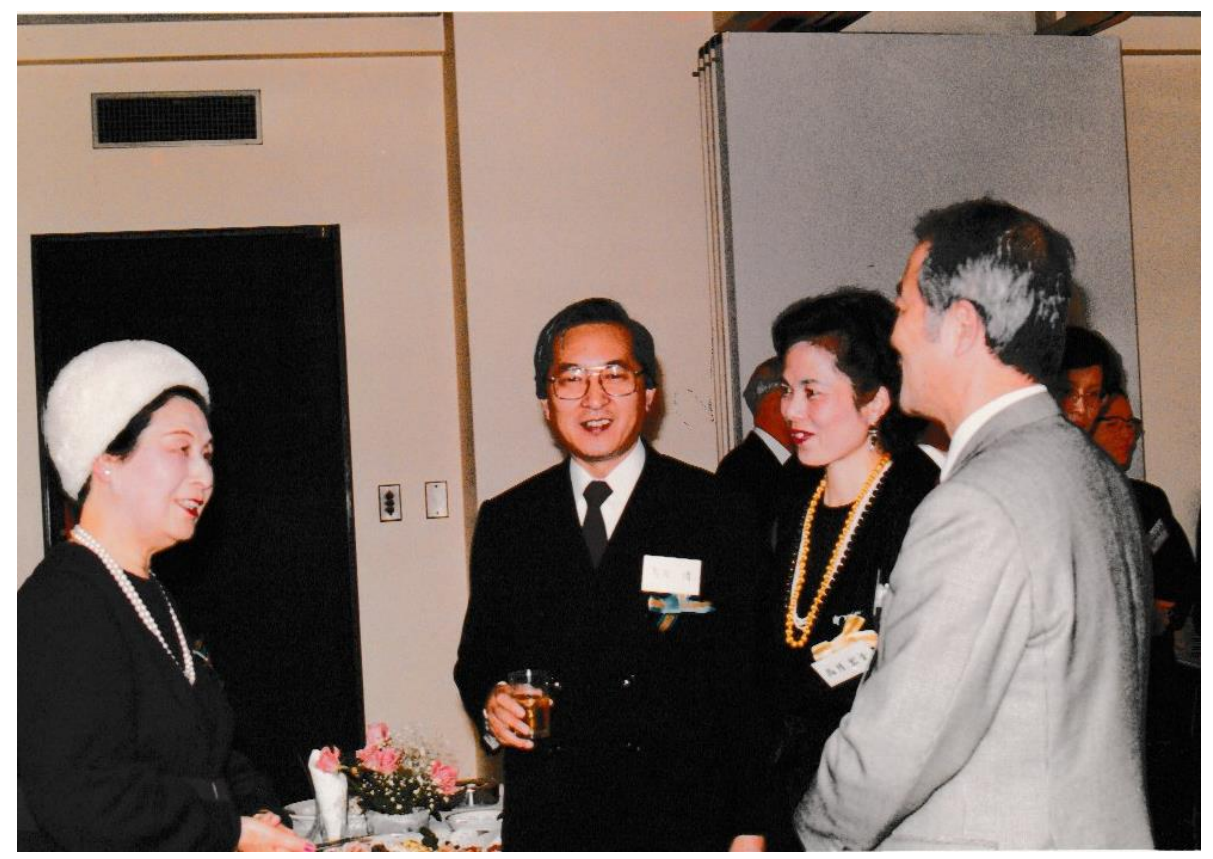

Figure 3. Prof. Takatsuki (center) and his wife, and Princess Takamatsu (left), at Princess Takamatsu cancer research fund prize (1983).

Conflicts of Interest: The author declares no conflict of interest.

\section{References}

1. Takatsuki, K.; Osserman, E.F. Structural Differences between 2 Types of "Heavy Chain" Disease Proteins and Myeloma Globulins of Corresponding Types. Science 1964, 145, 499-500. [CrossRef] [PubMed]

2. Osserman, E.F.; Takatsuki, K. Clinical and Immunochemical Studies of Four Cases of Heavy (H-Gamma-2) Chain Disease. Am. J. Med. 1964, 37, 351-373. [CrossRef]

3. Toyokuni, S.; Ebina, Y.; Okada, S.; Yamabe, H.; Ishikawa, T.; Uchiyama, T.; Yodoi, J.; Uchino, H.; Takatsuki, K. Report of a patient with POEMS/Takatsuki/Crow-Fukase syndrome associated with focal spinal pachymeningeal amyloidosis. Cancer 1992, 70, 882-886. [CrossRef] 
4. Takatsuki, K.; Sanada, I. Plasma cell dyscrasia with polyneuropathy and endocrine disorder: Clinical and laboratory features of 109 reported cases. Jpn. J. Clin. Oncol. 1983, 13, 543-555. [PubMed]

5. Takatsuki K, U.T.; Sagawa, K.; Yodoi, J. Adult T-Ccll Lcukemia in Japan; Irino, S.T.F., Irino, S., Eds.; Excerpta Medica: Amsterdam, The Netherlands, 1976.

6. Poiesz, B.J.; Ruscetti, F.W.; Gazdar, A.F.; Bunn, P.A.; Minna, J.D.; Gallo, R.C. Detection and isolation of type C retrovirus particles from fresh and cultured lymphocytes of a patient with cutaneous T-cell lymphoma. Proc. Natl. Acad. Sci. USA 1980, 77, 7415-7419. [CrossRef] [PubMed]

7. Robert-Guroff, M.; Nakao, Y.; Notake, K.; Ito, Y.; Sliski, A.; Gallo, R.C. Natural antibodies to human retrovirus HTLV in a cluster of Japanese patients with adult T cell leukemia. Science 1982, 215, 975-978. [CrossRef] [PubMed]

8. Blattner, W.A.; Takatsuki, K.; Gallo, R.C. Human T-cell leukemia-lymphoma virus and adult T-cell leukemia. JAMA 1983, 250, 1074-1080. [CrossRef] [PubMed]

9. Gallo, R.C.; Willems, L.; Tagaya, Y. Time to Go Back to the Original Name. Front. Microbiol. 2017, 8, 1800. [CrossRef] [PubMed]

10. Barre-Sinoussi, F.; Chermann, J.C.; Rey, F.; Nugeyre, M.T.; Chamaret, S.; Gruest, J.; Dauguet, C.; Axler-Blin, C.; Vezinet-Brun, F.; Rouzioux, C.; et al. Isolation of a T-lymphotropic retrovirus from a patient at risk for acquired immune deficiency syndrome (AIDS). Science 1983, 220, 868-871. [CrossRef] [PubMed]

11. Chagan-Yasutan, H.; Tsukasaki, K.; Takahashi, Y.; Oguma, S.; Harigae, H.; Ishii, N.; Zhang, J.; Fukumoto, M.; Hattori, T. Involvement of osteopontin and its signaling molecule CD44 in clinicopathological features of adult T cell leukemia. Leuk. Res. 2011, 35, 1484-1490. [CrossRef] [PubMed]

12. Chagan-Yasutan, H.; Lacuesta, T.L.; Ndhlovu, L.C.; Oguma, S.; Leano, P.S.; Telan, E.F.; Kubo, T.; Morita, K.; Uede, T.; Dimaano, E.M.; et al. Elevated levels of full-length and thrombin-cleaved osteopontin during acute dengue virus infection are associated with coagulation abnormalities. Thromb. Res. 2014, 134, 449-454. [CrossRef] [PubMed]

13. Hattori, T.; Chagan-Yasutan, H.; Shiratori, B.; Egawa, S.; Izumi, T.; Kubo, T.; Nakajima, C.; Suzuki, Y.; Niki, T.; Alisjahbana, B.; et al. Development of Point-of-Care Testing for Disaster-Related Infectious Diseases. Tohoku J. Exp. Med. 2016, 238, 287-293. [CrossRef] [PubMed]

14. Hattori, T. Case Reports Are the Starting Point to Medical Science. Reports 2020, 3, 8. [CrossRef]

15. Yodoi, J.; Takatsuki, K.; Masuda, T. Letter: Two cases of T-cell chronic lymphocytic leukemia in Japan. N. Engl. J. Med. 1974, 290, 572-573. [CrossRef] [PubMed]

16. Hattori, T.; Uchiyama, T.; Toibana, T.; Takatsuki, K.; Uchino, H. Surface phenotype of Japanese adult T-cell leukemia cells characterized by monoclonal antibodies. Blood 1981, 58, 645-647. [CrossRef] [PubMed]

17. Yamamura, Y.; Hattori, T.; Obaru, K.; Sakai, K.; Asou, N.; Takatsuki, K.; Ohmoto, Y.; Nomiyama, H.; Shimada, K. Synthesis of a novel cytokine and its gene (LD78) expressions in hematopoietic fresh tumor cells and cell lines. J. Clin. Investig. 1989, 84, 1707-1712. [CrossRef] [PubMed]

18. Hinuma, Y.; Nagata, K.; Hanaoka, M.; Nakai, M.; Matsumoto, T.; Kinoshita, K.I.; Shirakawa, S.; Miyoshi, I. Adult T-cell leukemia: Antigen in an ATL cell line and detection of antibodies to the antigen in human sera. Proc. Natl. Acad. Sci. USA 1981, 78, 6476-6480. [CrossRef] [PubMed]

19. Miyoshi, I.; Kubonishi, I.; Sumida, M.; Hiraki, S.; Tsubota, T.; Kimura, I.; Miyamoto, K.; Sato, J. A novel T-cell line derived from adult T-cell leukemia. Gan 1980, 71, 155-156. [PubMed] 